\title{
The Changes of Hong Kong Police Image in Hong Kong Film from CEPA
}

\author{
Qiang Zhou \\ Animation Academy \\ Communication University of Shanxi \\ Jinzhong, China \\ Department of Film Studies \\ Beijing Film Academy \\ Beijing, China
}

\begin{abstract}
This article mainly reviews and summarizes the changes of Hong Kong police image in Hong Kong gangster film since the CEPA was implemented in 2003. It explores the reasons and opportunities behind the change, explores the rules of the gangster crime and the cultural relationship between Hong Kong and the Mainland, Enrich Hong Kong gangster film research.
\end{abstract} CEPA

Keywords-Hong Kong gangster film; Hong Kong film;

\section{INTRODUCTION}

The gangster film is an important genre of film in Hong Kong. Hong Kong gangster film have started a story about conflicts between police and criminals and created a large number of popular police figures. Just as Professor Hao Jian defined the gangster film in "Film and Television Typology", "The gangster film is a type of film that depicts the clashes between police and law enforcement officers and gangsters and criminals." ${ }^{1}$ "The great success of the film "A Better Tomorrow"(1986) has made Hong Kong cops and robbers' films amenable to the vanguard of action films or comedy films in the past, for the first time having a completely mature genre. The 'Heroes' boom triggered by the "true character of the hero" has even made the Hong Kong cops and theaters become the mainstream of Hong Kong films in the late 1980s. Hong Kong cops and robbers arrived in the height of their history in the late 1980s at an unprecedented peak." ${ }^{2}$

In 2003, the Central Government and the HKSAR (Hong Kong Special Administrative Region Government) signed CEPA (the Closer Economic Partnership Arrangement). Then Hong Kong films entered the Mainland as coproductions. "The dynamic co-production of the film is a win-win result for the Hong Kong film and the mainland

Hao Jian: "Film and Television Typology", Peking University Press, 2002, 272

Xu Le: "Scanning Copies of Hong Kong Cops and Films, 19792005", Theory and Creation, 2006-03. film, so that some people simply put aside the title of "Hong Kong film" as the "Chinese film".

Faced with the new production environment, Hong Kong filmmakers began adjusted their production strategies. The most prominent feature was the police image in the movie. In this article, I will analyze the changes of police image in Hong Kong police gangster film.

\section{The High-INTELligence POLICE: From "COURAGE FIGHT" TO "WISE FIGHT"}

Since the "Infernal Affairs"(2002), there has been a clear change in Hong Kong cops and fools' films. The films that use the personal ability and the spectacle of the police as a selling point are declining. Films with the high IQ confrontation between the police and the criminals as the selling point are on the increase. In short, the move from "fighting courage" to "fighting wisdom" is mainly manifested in the police's struggle against criminals based on social rules such as logical reasoning ability, law, professional field knowledge, media and high-tech means.

The "Breaking News" (2004) directed by To Kai Fung tells the story of a Hong Kong police officer conducting live coverage of the arrest of robbers in an effort to restore the media image. The gangster film should have struggled around the conflict between the police and the criminals. However, there were two clues in the "Breaking News" (2004) in the struggle between the police and the military: one is the traditional struggle between the traditional police and the robbers represented by Zhang Zhiheng; the other is the new media police and robbers' media struggle. How the police did their job is to promptly transmit the heroic image of the police through the media. Every police officer who has been charged with the incident has become a video reporter who reports on-the-spot situations. The provisional police headquarters has become a television broadcasting center. As Kelly Chan said the phrase, "If he can use the media, he is a hero."

\footnotetext{
Zhou Qiang: "Hong Kong films have been in the Mainland for nearly three decades. Spread and Influence "," Popular Literature and Art ", 2014 , Issue 21
} 
Regardless of the director's attitude, or the plot of the story, the new media police obviously gained more attention and assumed the role of the main driving force of the story. The media police pay more attention to the image, more suitable for the media needs of the new era. Under the allmedia environment of the new era, the traditional police apparently relied on individual physical ability and went it alone to do their best life but did not achieve a satisfactory result. Those high-intelligence and calm media police are apparently welcomed by the public and the mass media.

\section{The Undercover POLICE: FAdED THE Holy AURA}

In writing techniques, "role conflict" is the best way to attract audiences, including the conflicts between the roles and roles in the story, the conflict between the roles and roles themselves. The more classic undercover characters in the gangster film are very much in line with this "conflict of roles" principle. First, as a police, "Undercover Police" has a very strong conflict with triad bandits, which is a conflict between roles and roles. Second, a law-abiding and upright justice "policeman" has been transformed into a "undercover" character and has been integrated into the criminal syndicate to break the laws and regulations and values that oneself possess. This is the role and value of one's own values conflict. Compared with the undercover police who had previously gained higher glory in the police aura, the cops and robbers since the CEPA showed more of the undercover police struggle and helplessness as ordinary people.

In the film "Protégé" (2007), undercover police Li was deeply trapped in the confusion and wandering of "role conflicts." In fact, it is about the choice of "morality" and "law." On one hand, he send the drug back to the police, on the other hand, he receive all the good service of drug lords brother, and finally accept the drug lord sister "devotion", then this character is in a very contradictory and struggling.

And the film repeatedly said: "Is the drug terrible, or is the emptiness terrible?" the film gives the answer, the emptiness is more terrible. Under the extremely empty circumstances, $\mathrm{Li}$ has a bearing on the drug-taking girl played by Zhang Jingchu and gradually assumes the responsibility of taking care of the family and becomes a misplaced "husband and father". He plunged into deep selfblame and thinking, caught in his own dual identity confusion. Instead of praising the merits of undercover cops, the film goes to make him suffer from dual identities, praised by the rule of law and cast aside by morals.

\section{THE FAMILY POLICE: FAMILY ETHICS INCREASED}

In the 1980s and 1990s, the police were basically lone heroic figures. Police officers tried their best to bring the criminals to justice and risked bloody battles. Their family background and family background were rarely studied. This situation did not change until "Infernal Affairs" in 2002. In the film, the policeman Andy Lau plays has a new wife and influences his series of motives, prompting him to aspire to be a good man. Since then, police in Hong Kong gangster films have listened to the words of Andy Lau, director of
Infernal Affairs, who warned Andy Lau: "When you get married, people will be more qualitative and give a good impression." A stable family, virtuous Wife, bright and lovely child, has become the standard of Hong Kong police.

In the film "New Police Story"(2004), Jackie Chan acting a police failed in one operation, resulting in the sacrifice of his girlfriend's brother, so he broke up with his girlfriend and became increasingly depressed and drunk. Later, with the help of Feng, Jackie Chan rekindled up, arresting criminals and bringing criminals back to the United States, fulfilling self-redemption and gaining the dual approval of feelings and heroic police. The impact of these family factors on the plot has shown its initial signs. The death of his brother-inlaw in the future left a shadow on the police, leaving the police to lose his girlfriend and fall into emotional predicament and career predicament, leave the shadow of life. The encounter with the Feng, makes the two "father and son partner" the establishment of the relationship, making Jackie Chan to regain the police dignity and motivation. We find that the elements of family ethics play become more and more important in the recent gangster films and have become an important factor in police motivation. The presence of the family makes the police image plumper and more acceptable. The police, like ordinary people, face the crisis of family. The film then excludes these motives to dig out the motives of the police and make the story more smooth and solid.

\section{THE DILEMMA POLICE: WHO WANDER BETWEEN "AFFECTION" AND "RULE OF LAW"}

Hong Kong gangster films have always been focusing on affection. Police identify with personal feelings, denial of the police system and even the legal system, has always been a character attractive place. "In the field of gangster film, the social system has never been an object that can be trusted and recognized. On the" police "side, the morality, justice and social conscience of ordinary people are the real things to be proclaimed and praised - Typical Representatives such as Li Xiuxian's 'Law with Two Phases' (1984), etc. ${ }^{4}$ However, since the CEPA, Hong Kong gangster film has a gradual emphasis on the legal system of contempt for affection. The boundary between the legal system and the affection is not so good as to grasp it. On the whole, however, the police in the gangsters in Hong Kong started to abandon the "affection" and move closer to the "legal system."

A typical example is "Cold War" (2012). The film was hijacked by a police car to start the story around the Hong Kong Police Office. Finally, they brought the criminals to justice and praised Hong Kong police for their superb ability. Quality, praised Hong Kong's spirit of the rule of law. In the first half of the film, conflicts center on the struggle between Deputy Director Li and Deputy Director Liu, and they compete for command of the operation in order to uphold different police concepts. Finally, with Director Liu's "rule by law procedure and the rule of law" The victory of the concept of action command.

\footnotetext{
$4 \quad$ Xu Le:" New Trends in Hong Kong Gangster Films Creation", "Contemporary Movies", Issue 3, 2012.
} 
The film "Z Storm"(2014) is particularly straightforward with the anti-corruption craze in the Mainland. Lu Zhilian in the film has great power in his hand and therefore faces the investigation of him by $\mathrm{L}$ group inside the ICAC. In his supervisor's words is "to prevent abuse of power, the power in the cage." In the movie "Z Storm2"(2016), the dual opposition of police officers and culprits in the traditional gangster films has become a battle for power between the police and the police. The personal subjectivity of the police surrenders to the huge political system. Under the restrictive rules within, fight for profit. "One of the producers of the film, Zhang Zhao, CEO of Le Vision Pictures, frankly stated that" anti-corruption storms "as the first film covering topics of financial corruption is now a more appropriate choice." 5

\section{ANALYSIS OF Hong Kong POLICE Vicissitude AFTER CEPA}

To sum up, there are mainly three reasons for the evolution of police image in Hong Kong's gangster films since CEPA.

First, Hong Kong gangster films have shaped such a rich police image. First, they have benefited from the innovation mechanism of Hong Kong genre film. After CEPA, Hong Kong filmmakers are confronted with new environments, censors, markets and audiences, forcing Hong Kong films to make new adjustments. In addition, Hong Kong film types are characterized by mixing, compounding and derivation, that is, the frequent blending number of a film Type and become a complex type of film.

Second, the restraint on the police by the power monitoring mechanism in the country exerts any influence on the creation of a gangster film. In the 21 st century, Hong Kong is a more rule of law and civilized Hong Kong. In the field of eavesdropping and monitoring, tapping listening and monitoring videos appearing in the films of gangsters as part of the state power mechanism at present have an increasing impact on the films, monitoring in public places, monitoring in the car, monitoring of information interrogations, law enforcement cases Surveillance, police have to face the state power to their own constraints and control.

Third, the subjective dissolution of the people of Hong Kong and the return of the institutional process in the gangster film presentation. Changes in the image of police in Hong Kong gangsters and films are inseparable from the economic and political conditions in Hong Kong. In the recent 10 years, Hong Kong's economic and political tendencies have become turbulent, and stable social and legal systems have become the most desired aspiration of people. In the midst of wandering, police officers robbed themselves of ethics, feelings and gradually moved closer to the family and the law. This is essentially the process by which the personal subjectivity of the police gradually moves closer to the social system. When we see the relationship between Hong Kong and the Mainland, it is actually Hong Kong

\footnotetext{
5 Mu Chenxi: Hong Kong films Hollywood Fan children
} Zhengnao Peninsula Morning News, "The Peninsula Morning News" A34 version, 2014-03-27.
Subdivision of the main body, the process of return to the Mainland.

\section{CONCLUSION}

To sum up, the image of police in Hong Kong gangsters is becoming more and more complicated. The police, who want to maintain their subjectivity but have to move closer to the system, are in line with the state of Hong Kong filmmakers on the mainland. Hong Kong filmmakers want to retain the characteristics of Hong Kong films. However, in the face of the Mainland's market and censorship environment, they gradually compromise and eventually merge into the historical wave of great development of Chinese-language films. On the other hand, since the CEPA, the mainland has become more important to Hong Kong's position. Hong Kong is gradually moving closer to the Mainland and taking the strategy of economic development in the Mainland. The HKSAR government needs to maintain a high degree of consistency with the Central Government, carry forward the spirit of the rule of law and build a harmonious society. In this process, some immature people in Hong Kong are trying to maintain their subjectivity but have to compromise under the broad environment and gradually integrate themselves into the Mainland's environment. So the wander and struggles they show in the process, And cops and robbers in the subjective dissolution of the police and the loss of return to the system, is one to one correspondence.

\section{REFERENCES}

[1] Liu Hui.2005.Analysis of Current Situation of Hong Kong Film Studies.

[2] Wang Haizhou.2003.Mirror and Culture - A Study of Hong Kong and Taiwan Cinema.

[3] David Bordwell.2000.The Secret of Hong Kong Films - The Art of Entertainment.

[4] Zhao Weifang.2007.The history of Hong Kong film. 